\title{
Breeding for Early Bearing in Olive
}

\author{
Lorenzo León ${ }^{1}$ and Raúl de la Rosa \\ IFAPA Centro Alameda del Obispo, CICE, Junta de Andalucia, Avda. \\ Menéndez Pidal, s/n, Apdo. 3092, E-14080, Córdoba, Spain
}

\section{Diego Barranco and Luis Rallo}

Departamento de Agronomía, Universidad de Córdoba, Campus de Rabanales, Edificio Celestino Mutis, Carretera Madrid-Cádiz, km 396, E-14014, Córdoba, Spain

Additional index words. cross-breeding, Olea europaea, vigor, yield efficiency

\begin{abstract}
The initial results of a comparative field trial of the first 15 selections of the olive (Olea europaea L.) breeding program of Cordoba, Spain, are presented. These selections came from crosses among 'Arbequina', 'Frantoio', and 'Picual' that were also included in the trial as controls. The trial was planted in July 2001 in a randomized block design with 16 replications and was systematically evaluated for earliness of bearing, vigor, crop, and yield efficiency from 2001 to 2005 . Significant differences among selections were found for all characters measured. A greater proportion of early-bearing genotypes than in previous cultivar collections were found, whereas mean accumulated yield was similar to former evaluations. Therefore, the shorter unproductive period obtained in this work seems to indicate that the selection of seedlings for a short juvenile period has provided a shorter unproductive period of the subsequent new cultivars. No correlation between vigor at the seedling stage and vigor in the corresponding adult vegetative propagated selection was found. If the data presented here are confirmed further, some early-bearing cultivars could be suggested as new olive cultivars, the first obtained by cross-breeding in Spain. Additionally, some of them also show a low vigor and could be adapted to high-density hedgerow orchards.
\end{abstract}

Olive plant material cultivated in all the Mediterranean areas, including Spain, is characterized by the abundance of very old cultivars restricted to specific areas where they originally appeared (Barranco and Rallo, 2000). The origin of olive domestication and growing has been explained by empirical selection of individuals for greater fruit size and oil yield content within wild olive populations and subsequent vegetative propagation, about $2800 \mathrm{BC}$ in the Middle East (Baldoni et al., 2006). This procedure, repeated in the traditional areas of cultivation, determines the current distribution of cultivars.

This situation is changing in the last few years, however, because many cultivars are unsuitable for a sustainable modern olive industry. As a consequence, some of the most important cultivars have spread outside their original area, such as 'Picual' and 'Arbequina' in Spain (Consejería de Agricultura y Pesca, 2003) or 'Leccino' and 'Frantoio' in Italy (Cimato, 1998). Nevertheless, reports on comparative field trials of olive cultivars from different origins are very scarce in all Mediterranean countries. At the same time, the need for more suitable cultivars prompted the development of olive breeding programs in the main

Received for publication 4 Jan. 2007. Accepted for publication 24 Feb. 2007.

This work has been supported in part by project RTA2005-00031-C02-01, National Institute of Agricultural Research, Ministry of Education and Culture, Spain.

${ }^{1}$ To whom reprint requests should be addressed; e-mail lorenzo.leon.ext@juntadeandalucia.es olive-producing countries based in intraspecific cross-breeding between cultivars of known merit aiming at combining the good qualities of the genitors in some of the genotypes of the progenies. Classic breeding programs by crossing and selection in the progenies are reported in Turkey (Arsel and Cirik, 1994), Tunisia (Trigui, 1996), Greece (Pritsa et al., 2003), Israel (Lavee et al., 1999, 2003), and Italy (Bellini et al., 2002a; Fontanazza et al., 1998). An attempt to select for quality oil production in feral olive populations is also ongoing in Australia (Sedgley, 2004). However, in contrast to other fruit trees, very few new breed cultivars have been reported in olive (Bellini et al., 2002b; Brooks and Olmo, 1997; Fontanazza et al., 1998; Lavee, 1978; Lavee et al., 1986, 1999, 2003, 2004).

In Spain, an olive breeding program was initiated in 1992 in Cordoba aimed at superseding the main cultivars in use (Rallo, 1995). Earliness of bearing and oil productivity were two of the main objectives of this breeding program. In olive, productivity has special interest for breeding because most olive cultivars were selected for extensive or traditional dry land systems of production. Therefore, the exploitation of the genetic potential for productivity at intensive growing could be still very limited (Lavee, 1990). The forced growth protocol to shorten the juvenile period and the results of the agronomic evaluation of seedling progenies performed in this breeding program have already been reported (León et al., 2004a, b; Santos-Antunes et al., 2005).

In this work, the results concerning earliness of bearing and initial crop and yield efficiency of a comparative field trial including 15 selections, from the previously cited seedling progenies, and their three genitors used as a control are reported. Comparison with the previous results of the corresponding seedling plants is also presented to define criteria for early selection.

\section{Material and Methods}

Plant material. The selections evaluated in this work come from the crosses and selfings, in the nine possible combinations of 'Arbequina', 'Frantoio', and 'Picual' olive cultivars carried out in 1992 and 1993. Seedlings obtained were subjected to a forcing growth protocol including germination of seeds, and greenhouse and field growth as described by Santos-Antunes et al. (2005). After three harvest seasons, 15 genotypes were selected from the initial population mainly on the basis of their early crop (short juvenile period) and high oil content, some of them also presenting outstanding values for other agronomic traits of interest (León et al., 2005). Vegetative propagation of those 15 selected genotypes and the three genitors, used as a control, was carried out by semihardwood stem cuttings in Spring 2000. Propagated trees were planted in an open field in July 2001 at $6 \times 5-\mathrm{m}$ spacing in a randomized block design with 16 replications and one tree per elementary plot. However, the design was unbalanced after the second year because of losses resulting from rodent damage (Table 1). Trees were trained as single-trunk vase, with three to four main branches, and minimal pruning was carried out to allow early bearing. Standard cultural practices were followed, including irrigation supply by in-line drips to avoid water stress of plants.

Traits evaluated. In the initial seedling population, genotypes producing flowers and, consequently, fruit were identified as reaching the adult phase during the first years after planting (Santos-Antunes et al., 2005). Height and trunk diameter before the beginning of each growing season, and fruit and oil yield of the individual seedlings in the first three harvest seasons were recorded (León et al., 2004b).

In the comparative field trial orchard containing the 15 selections and the three genitors, plants were systematically evaluated for earliness of bearing, vigor, crop, and yield efficiency in the 4 years after planting, from 2001 to 2005 . Height and trunk diameter prior the beginning of each growing season were recorded. In the last year (Feb. 2005), canopy height and width (measured east-west and north-south) were also recorded, and canopy surface and volume were calculated from these measurements (Del Río et al., 2005a). Trees were harvested as described for the initial seedling population, and fruit and oil yield of individual trees were recorded in 2003-2004, 2004-2005, and 2005-2006. Yield efficiency indexes were calculated as the ratios between cumulative yield (fruit yield, oil yield) and vigor measurements 
recorded in the last year (trunk cross-sectional area, canopy area, and canopy volume).

Data analysis. In the comparative field trial, average unproductive period was calculated by counting the number of bearing trees each year from 2003 to 2005 (2-4 years after planting). Agronomic data recorded (vigor, cumulated crop, and yield efficiency indexes) were subjected to analysis of variance to test the effect of genotypes, and separation of the means at $P<0.05$ were computed. Correlations between vigor and yield measurements obtained in the comparative field trial orchard and the initial seedling population were also calculated.

\section{Results and Discussion}

Earliness of bearing. The first significant bearing occurred 2 years after planting. The average unproductive period of the trial was 2.5 years and only 3 of the 18 genotypes evaluated showed unproductive periods more than 3 years (Table 1). Among the three genitors, 'Frantoio' showed a significantly longer unproductive period than 'Arbequina' and 'Picual' (3.2 years vs. 2.1 years, $t=5.75$, $P<0.001$ ), which confirms previous results in the evaluation of these cultivars (Del Río and Caballero, 1994). Similarly, selections having 'Frantoio' as a female genitor showed a significant longer unproductive period than those coming from 'Arbequina' and 'Picual' ( 2.9 years vs. 2.4 years, $t=5.31, P<0.001$ ). Considering the whole trial, 'Arbequina', 'UC-I 7-34', 'UC-I 9-67', and 'UC-I 5-44' showed the highest earliness of bearing, with more than $80 \%$ of trees bearing fruit 2 years after planting. These four genotypes, together with a second group of nine +genotypes including 'Picual', showed $100 \%$ of fruiting trees the next year, whereas only five additional genotypes, including 'Frantoio', showed $100 \%$ of fruiting trees only 4 years after planting.

The comparison of these results with those previously reported in the evaluation of olive cultivar collections and comparative field trials confirms the efficiency of selection for earliness of bearing in our breeding program. Thus, in the Olive Germplasm Bank of Cordoba, only $14 \%$ and $54 \%$ of 112 evaluated cultivars bore fruit 3 and 4 years after planting respectively (Del Río et al., 2005b). In the Olive Germplasm Bank of Catalonia, 8 and 12 of 30 evaluated cultivars bore fruit 2 and 3 years after planting respectively (Tous et al., 2005). Similarly, 5 of 10 cultivars evaluated in a comparative field trial in Catalonia bore their first fruit 2 to 3 years after planting (Tous et al., 2002). In Australia, a comparative field trial to evaluate the performance of 60 olive cultivars, representing most of the cultivars under cultivation, showed that $25 \%$ of them had no fruit set 3 years after planting (O'Sullivan, 2003). Therefore, the greater frequency of genotypes with short unproductive period obtained in this work seems to indicate that the selection of seedlings for a short juvenile period has also provided a shorter unproduc-
Table 1. Number of bearing trees by year and average unproductive period of the evaluated cultivars and selections.

\begin{tabular}{lcccrcrc}
\hline & & Planted & Surviving & \multicolumn{3}{c}{ Bearing trees } & Average \\
\cline { 5 - 6 } Genotype & Origin & trees (2001) & trees & 2003 & 2004 & 2005 & unproductive period (y) \\
\hline Arbequina (A) & - & 16 & 15 & 14 & 15 & 15 & 2.1 \\
Frantoio (F) & - & 16 & 15 & 2 & 10 & 15 & 3.2 \\
Picual (P) & - & 16 & 15 & 12 & 15 & 15 & 2.2 \\
UC-I 1-19 & $\mathrm{F} \times \mathrm{P}$ & 16 & 15 & - & 6 & 15 & 3.6 \\
UC-I 2-68 & $\mathrm{P} \times \mathrm{A}$ & 16 & 16 & 11 & 16 & 16 & 2.3 \\
UC-I 4-62 & $\mathrm{F} \times \mathrm{P}$ & 16 & 13 & 6 & 13 & 13 & 2.5 \\
UC-I 5-44 & $\mathrm{P} \times \mathrm{A}$ & 16 & 16 & 14 & 16 & 16 & 2.1 \\
UC-I 6-9 & $\mathrm{A} \times \mathrm{P}$ & 16 & 14 & 9 & 14 & 14 & 2.4 \\
UC-I 7-8 & $\mathrm{A} \times \mathrm{P}$ & 16 & 14 & 9 & 14 & 14 & 2.4 \\
UC-I 7-34 & $\mathrm{P} \times \mathrm{A}$ & 16 & 13 & 12 & 13 & 13 & 2.1 \\
UC-I 7-60 & $\mathrm{F} \times \mathrm{P}$ & 16 & 15 & 4 & 14 & 15 & 2.8 \\
UC-I 8-7 & $\mathrm{P} \times \mathrm{A}$ & 16 & 14 & 7 & 14 & 14 & 2.5 \\
UC-I 8-20 & $\mathrm{P} \times \mathrm{A}$ & 16 & 13 & 9 & 13 & 13 & 2.3 \\
UC-I 9-67 & $\mathrm{A} \times \mathrm{P}$ & 16 & 16 & 14 & 16 & 16 & 2.1 \\
UC-I 10-30 & $\mathrm{F} \times \mathrm{P}$ & 16 & 16 & 3 & 15 & 16 & 2.9 \\
UC-I 10-54 & $\mathrm{A} \times \mathrm{P}$ & 16 & 14 & 10 & 14 & 14 & 2.3 \\
UC-I 11-10 & $\mathrm{A} \times \mathrm{P}$ & 16 & 16 & 1 & 14 & 16 & 3.1 \\
UC-I 11-16 & $\mathrm{P} \times \mathrm{A}$ & 16 & 14 & 10 & 14 & 14 & 2.3 \\
Total & - & 288 & 264 & 147 & 246 & 264 & 2.5 \\
\hline
\end{tabular}

tive period of the subsequent new cultivars, as previously suggested (Santos-Antunes et al., 2005). The relationship between the length of the juvenile period and the unproductive period of the subsequent new cultivars has been reported in several fruit species. For instance, Visser (1970) suggested that selection for a short juvenile period in apple can be used to enhance breeding efficiency in three ways: shortening the first screening period of seedlings on their own roots in the orchard, shortening the second screening period of the vegetative propagated selections, and improving the chances of finding precocious varieties. Because a short unproductive period is a characteristic much appreciated by growers of an olive cultivar, it seems advisable to include a short juvenile period as a primary selection criterion in olive breeding programs.

Cumulative fruit and oil yield and vigor. Analysis of variance showed that genotype and block were the sources of variation responsible for $23 \%$ to $41 \%$ and $5 \%$ to $13 \%$ respectively of total sum of squares for productive and vigor measurements (Table 2). These results are similar to those previously reported in the evaluation of olive cultivar collections from data of a greater number of cultivars and only two to three trees per cultivar (Del Río et al., 2005b; Tous et al., 2005). Similar results have been also reported in the analysis of variance components of vigor, crop, and yield efficiency of 14 olive cultivars in Chile (Astorga and Mora, 2005).
Significant differences among genotypes were found in all parameters measured (Table 3). Mean accumulated fruit yield 4 years after planting ranged from 8.8 to 30.3 $\mathrm{kg} /$ tree among genotypes, averaging $17.9 \mathrm{~kg} /$ tree. 'Arbequina' and 'Picual' showed the highest accumulated fruit yield with no significant differences with 6 of the 15 selections tested. Ranking of genotypes according to oil yield showed some small changes resulting from differences in oil content among them. 'Arbequina' and 'UC-I 9-67' showed the highest oil yield, with no significant differences with 'Picual'. Some genotypes, such as 'UC-I 10-30', showed a greater oil yield than expected because of its high oil content. On the contrary, 'UC-I 7-8' showed a lower oil yield than expected because of its low oil content. Similar results, with greater ranges of variation, have been obtained in cultivar evaluations. Mean accumulated fruit yield during the first 3 years of bearing in the Olive Germplasm Bank of Cordoba varied from 2 to $52 \mathrm{~kg} /$ tree among cultivars, averaging $19 \mathrm{~kg} /$ tree, with $41 \%$ of cultivars yielding less than $14 \mathrm{~kg} /$ tree (Del Río et al., 2005b). In the Olive Germplasm Bank of Catalonia, yield ranged from 3 to $28 \mathrm{~kg}$ among cultivars, averaging $13.5 \mathrm{~kg} /$ tree, with $33 \%$ of cultivars yielding less than $14 \mathrm{~kg} /$ tree (Tous et al., 2005).

No correlation between yield and vigor measurements was obtained, which indicates that other factors should be responsible for the differences in yield observed among
Table 2. Percentage of total sum of squares and significance in the analysis of variance for productive and vigor measurements.

\begin{tabular}{lccccc}
\hline Source & $\begin{array}{c}\text { Cumulative } \\
\text { fruit yield }(\mathrm{kg} / \text { tree })\end{array}$ & $\begin{array}{c}\text { Cumulative oil } \\
\text { yield }(\mathrm{kg} / \mathrm{tree})\end{array}$ & $\begin{array}{c}\text { Trunk cross- } \\
\text { section }\left(\mathrm{cm}^{2}\right)\end{array}$ & $\begin{array}{c}\text { Canopy } \\
\text { volume }\left(\mathrm{m}^{3}\right)\end{array}$ & $\begin{array}{c}\text { Canopy } \\
\text { area }_{\left(\mathrm{m}^{2}\right)}\end{array}$ \\
\hline Genotype & $26.17^{* * *}$ & $22.75^{* * *}$ & $40.05^{* * *}$ & $36.78^{* * *}$ & $35.73^{* * *}$ \\
Block & $8.65^{*}$ & $12.91^{* * *}$ & 4.62 & $6.99 *$ & $8.53^{* * *}$ \\
Error & 65.18 & 64.34 & 55.33 & 56.23 & 55.75 \\
CV $(\%)$ & 52.55 & 56.90 & 35.48 & 37.65 & 26.44 \\
Mean & 17.89 & 3.86 & 31.78 & 3.64 & 12.06 \\
\hline
\end{tabular}

${ }^{*, * *, * * *}$ Significant at $P \leq 0.05,0.01$, and 0.001 respectively. 
Table 3. Mean values by cultivar for productive and vigor measurements.

\begin{tabular}{|c|c|c|c|c|c|}
\hline Genotype & $\begin{array}{l}\text { Cumulative fruit yield } \\
\qquad(\mathrm{kg} / \text { tree })\end{array}$ & $\begin{array}{c}\text { Cumulative oil yield } \\
(\mathrm{kg} / \text { tree })\end{array}$ & $\begin{array}{l}\text { Trunk cross-section } \\
\qquad\left(\mathrm{cm}^{2}\right)\end{array}$ & $\begin{array}{l}\text { Canopy volume } \\
\left(\mathrm{m}^{3}\right)\end{array}$ & $\begin{array}{l}\text { Canopy area } \\
\left(\mathrm{m}^{2}\right)\end{array}$ \\
\hline$\overline{\text { Arbequina }}$ & $30.25 \mathrm{a}^{\mathrm{z}}(1)^{\mathrm{y}}$ & $6.63 \mathrm{a} \mathrm{(1)}$ & 34.74 bcde $(8)$ & 4.00 cde $(7)$ & $13.41 \mathrm{bc}(5)$ \\
\hline Frantoio & $8.81 \mathrm{~g}(18)$ & $1.74 \mathrm{f}(18)$ & 55.77 a (1) & $6.02 \mathrm{a}(1)$ & $17.24 \mathrm{a}(1)$ \\
\hline Picual & $25.68 \mathrm{ab}(2)$ & $4.99 \mathrm{abc}(3)$ & 29.77 cdefg (10) & 3.30 defg (11) & 11.14 cde (11) \\
\hline UC-I 1-19 & 12.73 efg (15) & $3.09 \mathrm{cdef}(14)$ & 37.15 bc (3) & $4.27 \mathrm{bcd}(4)$ & $12.80 \mathrm{bc}(7)$ \\
\hline UC-I 2-68 & 20.15 bcde (5) & $4.19 \mathrm{~cd}(8)$ & 27.62 cdefg (12) & $2.91 \mathrm{efg}(12)$ & 10.79 cde (12) \\
\hline UC-I 4-62 & $9.55 \mathrm{fg}(17)$ & $2.58 \operatorname{def}(16)$ & 28.48 cdefg (11) & $4.21 \mathrm{bcd}(5)$ & $13.24 \mathrm{bc}(6)$ \\
\hline UC-I 5-44 & $9.88 \mathrm{fg}(16)$ & 2.27 ef (17) & 26.04 defg (13) & 2.87 efg (13) & 10.60 cde (13) \\
\hline UC-I 6-9 & 15.96 defg (13) & $3.16 \mathrm{cdef}(13)$ & $19.86 \mathrm{gh}(17)$ & $2.29 \mathrm{~g} \mathrm{(17)}$ & 8.34 e $(18)$ \\
\hline UC-I 7-8 & 18.14 bcde (8) & $2.96 \operatorname{def}(15)$ & 25.20 efg (14) & $2.54 \mathrm{fg}(15)$ & $9.27 \mathrm{de}(15)$ \\
\hline UC-I 7-34 & $22.39 \mathrm{bcd}(4)$ & 4.33 bcd (6) & $40.85 \mathrm{~b}(2)$ & $3.56 \operatorname{cdef}(9)$ & $12.76 \mathrm{bc}(8)$ \\
\hline UC-I 7-60 & 17.04 cdef (11) & $3.32 \mathrm{cdef}(11)$ & $36.50 \mathrm{bc}(5)$ & 3.60 cdef (8) & $12.49 \mathrm{bc}(9)$ \\
\hline UC-I 8-7 & $17.56 \operatorname{cdef}(9)$ & $3.63 \mathrm{cdef}(10)$ & 24.19 fgh (15) & $2.53 \mathrm{fg}(16)$ & 9.62 de (14) \\
\hline UC-I 8-20 & 19.82 bcde $(6)$ & $4.38 \mathrm{bcd}(5)$ & 35.77 bcd (6) & $5.29 \mathrm{ab}(2)$ & $15.17 \mathrm{ab}(2)$ \\
\hline UC-I 9-67 & $24.90 \mathrm{abc}(3)$ & $6.09 \mathrm{ab}(2)$ & $35.51 \mathrm{bcd}(7)$ & 4.76 bc (3) & $14.35 \mathrm{~b}(3)$ \\
\hline UC-I 10-30 & 16.95 cdef (12) & 4.46 bcd (4) & 36.76 bc (4) & $4.20 \mathrm{bcd}(6)$ & $14.22 \mathrm{~b}(4)$ \\
\hline UC-I 10-54 & 14.19 efg (14) & $3.25 \mathrm{cdef}(12)$ & 21.19 fgh (16) & $2.66 \mathrm{fg}(14)$ & 9.17 de (16) \\
\hline UC-I 11-10 & 19.54 bcde (7) & $4.24 \mathrm{~cd}(7)$ & $30.57 \operatorname{cdef}(9)$ & $3.36 \mathrm{defg}(10)$ & $11.40 \mathrm{~cd}(10)$ \\
\hline UC-I 11-16 & 17.52 cdef $(10)$ & 3.69 cde $(9)$ & $15.92 \mathrm{~h}(18)$ & $2.22 \mathrm{~g}(18)$ & 8.46 e $(17)$ \\
\hline
\end{tabular}

${ }^{\mathrm{z}}$ Different letters indicate significant differences at $P \leq 0.05$.

${ }^{y}$ Ranking order in parentheses.

Table 4. Percentage of total sum of squares and significance in the analysis of variance for cumulative yield efficiency indexes.

\begin{tabular}{|c|c|c|c|c|c|c|}
\hline Source & $\begin{array}{l}\text { Fruit yield }(\mathrm{kg}) / \text { trunk } \\
\text { cross-section }\left(\mathrm{cm}^{2}\right)\end{array}$ & $\begin{array}{c}\text { Fruit yield }(\mathrm{kg}) / \text { canopy } \\
\text { volume }\left(\mathrm{m}^{3}\right)\end{array}$ & $\begin{array}{c}\text { Fruit yield }(\mathrm{kg}) / \text { canopy } \\
\text { area }\left(\mathrm{m}^{2}\right)\end{array}$ & $\begin{array}{l}\text { Oil yield }(\mathrm{kg}) / \text { trunk } \\
\text { cross-section }\left(\mathrm{cm}^{2}\right)\end{array}$ & $\begin{array}{l}\text { Oil yield }(\mathrm{kg}) / \text { canopy } \\
\text { volume }\left(\mathrm{m}^{3}\right)\end{array}$ & $\begin{array}{c}\text { Oil yield }(\mathrm{kg}) / \text { canopy } \\
\text { area }\left(\mathrm{m}^{2}\right)\end{array}$ \\
\hline Genotype & $60.72 * * *$ & $62.64 * * *$ & $57.20 * * *$ & $51.55^{* * *}$ & $56.08 * * *$ & $44.59 * * *$ \\
\hline Block & 3.22 & 2.47 & 2.68 & $7.34 * *$ & 4.78 & $6.88^{*}$ \\
\hline Error & 36.06 & 34.89 & 40.12 & 41.15 & 39.14 & 48.53 \\
\hline $\mathrm{CV}(\%)$ & 35.17 & 33.49 & 33.08 & 38.43 & 33.36 & 36.53 \\
\hline Mean & 0.64 & 5.73 & 1.60 & 0.13 & 1.19 & 0.33 \\
\hline
\end{tabular}

*,**,**** Significant at $P \leq 0.05,0.01$, and 0.001 respectively.

Table 5. Mean values by cultivar for yield efficiency parameters.

\begin{tabular}{|c|c|c|c|c|c|c|}
\hline Genotype & $\begin{array}{c}\text { Fruit yield } \\
(\mathrm{kg}) / \text { trunk } \\
\text { cross-section }\left(\mathrm{cm}^{2}\right)\end{array}$ & $\begin{array}{c}\text { Fruit yield } \\
(\mathrm{kg}) / \text { canopy } \\
\text { volume }\left(\mathrm{m}^{3}\right)\end{array}$ & $\begin{array}{l}\text { Fruit yield } \\
(\mathrm{kg}) / \text { canopy } \\
\text { area }\left(\mathrm{m}^{2}\right)\end{array}$ & $\begin{array}{c}\text { Oil yield } \\
(\mathrm{kg}) / \text { trunk } \\
\text { cross-section }\left(\mathrm{cm}^{2}\right)\end{array}$ & $\begin{array}{c}\text { Oil yield } \\
(\mathrm{kg}) / \text { canopy } \\
\text { volume }\left(\mathrm{m}^{3}\right)\end{array}$ & $\begin{array}{c}\text { Oil yield } \\
(\mathrm{kg}) / \text { canopy } \\
\text { area }\left(\mathrm{m}^{2}\right)\end{array}$ \\
\hline Arbequina & $0.89 b^{z}(4)^{y}$ & 7990 bcd (4) & $2.27 \mathrm{ab}(4)$ & $0.19 \mathrm{~b}(2)$ & $1.69 \mathrm{~b}(2)$ & $0.49 \mathrm{ab}(2)$ \\
\hline Frantoio & $0.14 \mathrm{i}(18)$ & $1426 \mathrm{~m}(18)$ & $0.49 \mathrm{~g}(18)$ & $0.03 \mathrm{~h} \mathrm{(18)}$ & $0.27 \mathrm{i}(18)$ & $0.10 \mathrm{~h}(18)$ \\
\hline Picual & $0.95 \mathrm{~b}(2)$ & 8731 abc (3) & $2.44 \mathrm{a}(3)$ & $0.18 \mathrm{~b} \mathrm{(3)}$ & $1.65 \mathrm{~b} \mathrm{(3)}$ & $0.46 \mathrm{abc}(3)$ \\
\hline UC-I 1-19 & $0.33 \mathrm{~h}(16)$ & $2824 \mathrm{klm}(16)$ & $0.93 \mathrm{fg}(15)$ & $0.08 \mathrm{~g} \mathrm{(16)}$ & $0.65 \mathrm{gh}(16)$ & $0.22 \mathrm{fg}(15)$ \\
\hline UC-I 2-68 & 0.71 cde $(8)$ & 7134 cde $(7)$ & 1.84 bcd (7) & $0.15 \mathrm{bcd}(10)$ & $1.47 \mathrm{bc}(7)$ & 0.38 bcd (9) \\
\hline UC-I 4-62 & $0.32 \mathrm{~h}(17)$ & $2176 \operatorname{lm}(17)$ & $0.69 \mathrm{~g}(17)$ & $0.08 \mathrm{fg}(15)$ & 0.57 hi (17) & $0.18 \mathrm{gh}(17)$ \\
\hline UC-I 5-44 & $0.35 \mathrm{~h}(15)$ & $3361 \mathrm{jkl}(15)$ & $0.88 \mathrm{fg}(16)$ & $0.08 \mathrm{~g}(17)$ & $0.74 \mathrm{gh}(15)$ & $0.20 \mathrm{fg}(16)$ \\
\hline UC-I 6-9 & 0.86 bcd (6) & $7681 \mathrm{~cd}(5)$ & $2.04 \mathrm{abc}(5)$ & $0.17 \mathrm{bc}(5)$ & $1.54 \mathrm{bc}(5)$ & $0.41 \mathrm{bcd}(4)$ \\
\hline UC-I 7-8 & $0.91 \mathrm{~b}(3)$ & $9455 \mathrm{ab}(2)$ & $2.48 \mathrm{a}(1)$ & 0.15 bcd (9) & $1.51 \mathrm{bc}(6)$ & $0.40 \mathrm{bcd}(6)$ \\
\hline UC-I 7-34 & 0.55 efg (12) & $6824 \operatorname{def}(8)$ & $1.77 \mathrm{~cd}(9)$ & $0.11 \mathrm{defg}(13)$ & $1.27 \mathrm{~cd}(10)$ & 0.34 de (11) \\
\hline UC-I 7-60 & $0.50 \mathrm{fgh}(13)$ & 4861 ghij (12) & 1.39 de (12) & 0.10 efg (14) & 0.93 efg (13) & 0.27 efg (14) \\
\hline UC-I 8-7 & $0.86 \mathrm{bcd}(5)$ & $7559 \mathrm{~cd}(6)$ & 1.89 bc (6) & $0.18 \mathrm{~b}(4)$ & $1.55 \mathrm{bc}(4)$ & $0.39 \mathrm{bcd}(8)$ \\
\hline UC-I 8-20 & 0.61 efg (11) & 4040 ijk (14) & $1.38 \mathrm{de}(13)$ & 0.13 cde (11) & 0.87 fgh (14) & $0.30 \operatorname{def}(13)$ \\
\hline UC-I 9-67 & $0.68 \operatorname{def}(10)$ & 5238 fghi (11) & $1.69 \mathrm{~cd}(10)$ & 0.16 bc (7) & 1.24 cde (11) & $0.40 \mathrm{bcd}(5)$ \\
\hline UC-I 10-30 & $0.48 \mathrm{gh}(14)$ & 4142 hijk (13) & 1.22 ef (14) & 0.13 cdef (12) & $1.09 \operatorname{def}(12)$ & 0.32 de $(12)$ \\
\hline UC-I 10-54 & 0.72 cde $(7)$ & 5694 efgh (10) & 1.61 cde $(11)$ & $0.16 \mathrm{bc}(6)$ & $1.28 \mathrm{~cd}(9)$ & 0.36 cde $(10)$ \\
\hline UC-I 11-10 & $0.69 \operatorname{def}(9)$ & 6356 defg (9) & $1.81 \mathrm{~cd}(8)$ & 0.15 bcd (8) & 1.37 bcd (8) & $0.39 \mathrm{bcd}(7)$ \\
\hline UC-I 11-16 & $1.35 \mathrm{a}(1)$ & 9814 a (1) & $2.45 \mathrm{a}(2)$ & $0.29 \mathrm{a}(1)$ & $2.10 \mathrm{a}(1)$ & $0.52 \mathrm{a}(1)$ \\
\hline
\end{tabular}

${ }^{\mathrm{z}}$ Different letters indicate significant differences at $P \leq 0.05$.

${ }^{y}$ Ranking order in parentheses.

genotypes. This lack of correlation has been previously suggested in olive (Del Río and García-Fernández, 2001). 'Frantoio' is the genotype with the greatest vigor, which confirms previous evaluations in cultivar collections (Del Río et al., 2005a). Only 'UC-I $8-20$ ' has a similar high vigor. 'UC-I 11-16', 'UC-I 6-9', 'UC-I 8-7', UC-I 7-8', and 'UC-I $10-54$ ' are the selections with the least vigor. Ranking of genotypes according to vigor was very similar with the different vigor measurements evaluated (trunk cross-sectional area, canopy area, and canopy volume), because of the close relationship between these vigor measurements (correlation coefficients higher than $0.8, P<0.001$ among them). A significant relationship among different vigor measurements has been previously reported in olive (Del Río et al., 2005a; O'Sullivan, 2003). Therefore, trunk diameter (the easiest parameter to measure) could be enough for vigor characterization of cultivars, at least during the initial stages of growth, with the consequent savings in effort.

No correlation was found between vigor or yield measurements recorded in the initial seedling population with the corresponding measurements obtained in the comparative field trial orchard. Previous results in our breeding program indicate the complexity of evaluation for yield in the initial seedling populations and, therefore, the difficulties of selection for this characteristic (León et al., 2004b). Therefore, selection for yield in breeding progenies should be attempted only in advanced, or at least in intermediate, stages of selection using several plants per genotype. Productivity is probably the main goal for any plant breeder, but the problem of evaluation has discouraged a systematic or deliberated effort to breed for yield. For instance, in other fruit species, many of the highest yielding cultivars (e.g., 'Bartlett' pear or 'Golden Delicious' apple) arose as chance seedlings, which reflects how far fruit breeding for yield has yet to come (Way et al., 1983). In olive, the difficulties of assessing the relative yielding ability of the new genotypes, which is 
expensive and time-consuming, results in the fact that most olive breeding programs have simply not attempted to evaluate productivity in the seedling stage.

On the other hand, an early selection for a short juvenile period on the basis of high vigor in the initial seedling plants in the greenhouse has been suggested (De la Rosa et al., 2006). Because there is no correlation between vigor in the seedling stage and vigor in the corresponding adult vegetative propagated selection, this initial selection for high vigor in the greenhouse does not imply that all the selections subsequently obtained would be vigorous. On the contrary, a considerable variability in vigor was obtained in the 15 selections evaluated, which could permit the final selection of cultivars adapted to different planting systems.

Early yield efficiency. Genotype and block were responsible for $45 \%$ to $63 \%$ and $2 \%$ to $7 \%$ respectively of total sum of squares for yield efficiency parameters (both in fruit and oil; Table 4). As a consequence of the high correlation between the different vigor measurements, ranking of the genotypes according to yield efficiency was similar in all cases, with 'UC-I 11-16', 'UC-I 8-7', 'UC-I 6-9', 'UC-I 7-8', 'Arbequina', and 'Picual' being the genotypes with the highest values for these characteristics (Table 5). Yield efficiency is usually referred to as accumulated yield per unit of vigor calculated after trees reach the productive stage, usually after 9 to 10 bearing seasons. Therefore, the results obtained in this work related to this parameter should be considered only as preliminary. The four selections mentioned earlier, 'UC-I 11-16', 'UC-I 8-7', 'UC-I 6-9', and 'UC-I 7-8', showed high productivity and low vigor, and could be particularly interesting for high-density hedgerow orchards, a new concept of olive orchard that came up in the late 1990s and demands new specifically adapted cultivars (De la Rosa et al., 2007). Their possible use as rootstocks to control vigor could be also explored.

\section{Conclusion}

In summary, the results on vigor and crop of this comparative trial of 15 advanced selections in relation to the genotype evaluation data of the original seedlings emphasizes the usefulness of criteria used for selection by earliness of bearing in both phases of the breeding process. They also allow the identification of several new cultivars with early bearing and high early yield (both in fruit and oil). Some of them also present low vigor and could be, therefore, be particularly adapted to a high-density mechanically harvested orchard. This work should be continued to obtain a proper evaluation of the commercial productivity of cultivars. However, the preliminary results reported here provided information of bearing in early years, which in perennial crops could be, in some cases, as important as total lifetime yield as a result of the necessity for a fast return of the cost of establishment.

\section{Literature Cited}

Arsel, H. and N. Cirik. 1994. A general overview of olive breeding in Turkey. Olivae 52:25-27.

Astorga, M. and F. Mora. 2005. Componentes de varianza e interacción variedad-sitio del vigor, producción y productividad de Olea europaea, en Chile. Cerne Lavras 11:25-33.

Baldoni, L., N. Tosti, C. Ricciolini, A. Belaj, S. Arcioni, G. Pannelli, M.A. Germana, M. Mulas, and A. Porceddu. 2006. Genetic structure of wild and cultivated olives in the central Mediterranean basin. Ann. Bot. (Lond.) 98:935-942.

Barranco, D. and L. Rallo. 2000. Olive cultivars in Spain. HortTechnology 10:107-110.

Bellini, E., E. Giordani, M.V. Parlati, and S. Pandolfi. 2002a. Olive genetic improvement: Thirty years of research. Acta Hort. 586:105-108.

Bellini, E., M.V. Parlati, and E. Giordani. 2002b. Three new olive cultivars obtained by crossbreeding. Acta Hort. 586:221-223.

Brooks, R.M. and H.P. Olmo. 1997. The Brooks and Olmo register of fruit $\&$ nut varieties. 3rd ed. ASHS Press, Alexandria, Va.

Cimato, A. 1998. Genetic resources as a means of optimising production. Olivae 73:44-48.

Consejería de Agricultura y Pesca. (2003). El olivar andaluz. Junta de Andalucía, Consejería de Agricultura y Pesca, Sevilla, Spain.

De la Rosa, R., N. Guerrero, L. Rallo, D. Barranco, and L. León. 2007. Preliminary results of an olive cultivar trial at high density. Austral. J. Agr. Res. (In press).

De la Rosa, R., A.I. Kiran, D. Barranco, and L. León. 2006. Seedling vigor as a preselection criterion for short juvenile period in olive breeding. Austral. J. Agr. Res. 57:477-481.

Del Río, C. and J.M. Caballero. 1994. Preliminary agronomical characterization of 131 cultivars introduced in the olive germplasm bank of Córdoba in March 1987. Acta Hort. 356: $110-115$.

Del Río, C., J.M. Caballero, and M.D. GarcíaFernández. 2005a. Vigor (Banco de Germoplasma de Córdoba). In: L. Rallo, D. Barranco, J. Caballero, A. Martín, C. del Río, J. Tous, and I. Trujillo (eds.). Las variedades de olivo cultivadas en España (Libro II: Variabilidad y selección). Junta de Andalucía, MAPA and Ediciones Mundi-Prensa, Madrid, Spain.

Del Río, C., J.M. Caballero, and M.D. GarcíaFernández. 2005b. Producción (Banco de Germoplasma de Córdoba). In: L. Rallo, D. Barranco, J. Caballero, A. Martín, C. del Río, J. Tous, and I. Trujillo (eds.). Las variedades de olivo cultivadas en España (Libro II: Variabilidad y selección). Junta de Andalucía, MAPA and Ediciones Mundi-Prensa, Madrid, Spain.

Del Río, C. and M.D. García-Fernández. 2001. Clasificación de variedades de olivo por precocidad de entrada en producción y su relación con el vigor de la planta. Fruticultura Profesional 120:61-65.

Fontanazza, G., F. Bartolozzi, and G. Vergari. 1998. Fs-17. Riv. Frutticoltura 5:61.

Lavee, S. 1978. 'Kadesh' table olive. HortScience 13:62-63.

Lavee, S. 1990. Aims, methods and advances in breeding of new olive (Olea europaea, L.) cultivars. Acta Hort. 286:23-36.
Lavee, S., N. Avidan, and Y. Meni. 2003. 'Askal', a new high-performing oil variety for intensive and super-intensive olive orchards. Olivae 97: $53-59$.

Lavee, S., B. Avidan, Y. Meni, A. Haskal, and M. Wodner. 2004. Three new semi-dwarf tableolive varieties. Olivae 102:33-41.

Lavee, S., H. Harshemesh, A. Haskal, V. Meni, M. Wodner, A. Ogrodovich, B. Avidan, Z. Wiesman, N. Avidan, and A. Trapero-Casas. 1999. 'Maalot' a new orchard-resistant cultivar to peacock eye leaf spot (Spilocaea oleagina Cast.). Olivae 78:51-59.

Lavee, S., A. Haskal, and M. Wodner. 1986. 'Barnea' a new olive cultivar from first breeding generation. Olea 17:95-99.

León, L., L.M. Martín, and L. Rallo. 2004a. Phenotypic correlations among agronomic traits in olive progenies. J. Amer. Soc. Hort. Sci. 129:271-276.

León, L., L. Rallo, C. Del Río, and L.M. Martín. 2004b. Variability and early selection on the seedling stage for agronomic traits in progenies from olive crosses. Plant Breed. 123:73-78.

León, L., A.F. Santos-Antunes, L.M. Martín, A. Garrido, and L. Rallo. 2005. Obtención de nuevas variedades por cruzamientos. In: L. Rallo, D. Barranco, J. Caballero, A. Martín, C. del Río, J. Tous, and I. Trujillo (eds.). Las variedades de olivo cultivadas en España (Libro III: Mejora genética y biotecnología). Junta de Andalucía, MAPA and Ediciones Mundi-Prensa, Madrid, Spain.

O'Sullivan, G. 2003. Olive variety assessment. RIRDC publication no. 03/021, Rural Industries Research and Development Corporation, Barton, Australia.

Pritsa, T.S., D.G. Voyiatzis, C.J. Voyiatzi, and M.S. Sotiriou. 2003. Evaluation of vegetative growth traits and their relation to time to first flowering of olive seedlings. Austral. J. Agr. Res. 54:371-376.

Rallo, L. 1995. Selection and breeding of olive in Spain. Olivae 59:46-53.

Santos-Antunes, A.F., L. León, R. De la Rosa, J. Alvarado, A. Mohedo, I. Trujillo, and L. Rallo. 2005. The length of the juvenile period of olive seedlings as influenced by vigor and the choose of genitors. HortScience 40:1213-1215.

Sedgley, M. 2004. Wild olive selection for quality oil production. RIRDC publication no. 04/101, Rural Industries Research and Development Corporation, Barton, Australia.

Trigui, A. 1996. Improving the quantity and quality of olive production in Tunisia: Unavoidable need and outlook for olive identification and breeding. Olivae 61:34-40.

Tous, J., A. Romero, J. Plana, and J.F. Hermoso. 2002. Behaviour of ten Mediterranean olive cultivars in the North-East of Spain. Acta Hort. 586:113-116.

Tous, J., A. Romero, and J. Plana. 2005. Producción (Banco de Germoplasma de Cataluña). In: L. Rallo, D. Barranco, J. Caballero, A. Martín, C. del Río, J. Tous, and I. Trujillo (eds.). Las variedades de olivo cultivadas en España (Libro II: Variabilidad y selección). Junta de Andalucía, MAPA and Ediciones MundiPrensa, Madrid, Spain.

Visser, T. 1970. The relation between growth, juvenile period and fruiting of apple seedlings and its use to improve breeding efficiency. Euphytica 19:293-302.

Way, R.D., J.C. Sanford, and A.N. Lakso. 1983. Fruitfulness and productivity. In: J.N. Moore and J. Janick (eds.). Methods in fruit breeding. Purdue Univ. Press, West Lafayette, Ind. 